\title{
Achieving the DREAM: The Effect of IRCA on Immigrant Youth Postsecondary Educational Access
}

\author{
By Kalena E. CoRtes*
}

In 1982, the landmark US Supreme Court ruling in Plyler v. Doe granted undocumented immigrant students access to free public schooling. The ruling, however, did not address postsecondary education. Federal laws have prevented undocumented students from receiving financial benefits to attend college, creating financial and legal barriers between students and the American dream. ${ }^{T}$

Over the past decade, there have been several unsuccessful attempts to pass the controversial DREAM Act (Development, Relief, and Education for Alien Minors). The Act would provide conditional permanent residency to undocumented youths who graduate from US high schools after having arrived in the United States as minors, and having lived in the country continuously for at least five years prior to the bill's enactment. Proponents argue that the measure would alleviate the inequalities experienced by students whose parents brought them to the United States as young children; opponents claim that it would pave the way for a future blanket amnesty. On June 15, 2012, the Obama administration announced a policy directive to grant deferred action to a certain group of undocumented immigrants. While the directive is similar in scope to DREAM Act proposals, it is neither a legislative act nor an executive order.

\footnotetext{
*Texas A\&M University, 4220 TAMU, 1049 Allen Building, College Station, TX, 77843, and IZA (Institute for the Study of Labor) (e-mail: kcortes@tamu.edu). I would like to thank Jeremy B. Twitchell for excellent research assistance. Also, I would like to thank the session participants at the Association for Public Policy Analysis and Management, the Association for Education Finance and Policy, and the American Economic Association.

${ }^{\dagger}$ To view additional materials, and author disclosure statement(s),visit the article page at http://dx.doi.org/10.1257/aer.103.3.428.

${ }^{1}$ Title IV of the Higher Education Act of 1965 forbids undocumented students from receiving federal aid for postsecondary education.
}

There are an estimated 4.4 million undocumented immigrants under age 30 in the United States and of these, an estimated 1.7 million (39 percent) would be eligible for deferred action under the policy directive (Passel and Lopez 2012).

To date, more than ten states have enacted laws that qualify undocumented students for in-state tuition fees rather than the higher fees nonresidents pay. ${ }^{2}$ While the number of states to have passed such laws is growing, only a handful of studies have analyzed the effects of these state policies on the educational attainment of undocumented immigrant youth (Kaushal 2008; Flores 2010; and Chin and Juhn 2010). Kaushal (2008) finds that allowing undocumented students access to in-state tuition increases college enrollment within that group by 2.5 percentage points - an increase of more than 30 percent over a base mean of 8 percent.

This paper contributes to the existing literature examining the effect of legal status on the educational access of immigrant youth in the United States. Specifically, I use a difference-in-differences framework to analyze the effect of the Immigration Reform and Control Act (IRCA) of 1986, which granted amnesty to undocumented immigrants who entered the United States before January 1, 1982 and resided there continuously. So far, most studies on the effects of IRCA have provided thorough analyses of the law's effect on labor market outcomes among adult immigrants who benefited from the amnesty program. All these studies have found positive effects of IRCA on earnings (see, for example, Rivera-Batiz 1999;

\footnotetext{
${ }^{2}$ These states include CA, CT, IL, KS, MA, MD, NE, NM, NY, OK, TX, UT, and WA. Wisconsin enacted a similar law in 2009 but then revoked that law in 2011.
} 
Kossoudji and Cobb-Clark 2002; AmuedoDorantes, Bansak, and Raphael 2007; AmuedoDorantes and Bansak 2011; and Pan 2012). Yet none has analyzed IRCA's effect on the educational attainment of the immigrant children to whom it gave amnesty. With the IRCA children having now come of age, the present study assesses the effect of this large amnesty program on their access to postsecondary education.

The analysis here has two advantages over the previous studies. First, although the earlier research exploits state-time variation in the passage of the state laws to estimate effects on college enrollment of Hispanic immigrant youth, these studies may suffer from legislative endogeneity. States that adopted such legislative policies may be vastly different from those that did not. The identification strategy I apply here exploits instead a national reform. Second, the previous studies consider only Hispanic immigrant youth. While this subgroup of immigrants clearly is important to analyze, I assess an overall impact of IRCA on all immigrant youth and provide estimates for immigrant subgroups. My main finding shows that immigrant youth who were granted amnesty under IRCA are more likely to enroll in postsecondary education.

\section{Empirical Strategy and Data}

This paper uses a difference-in-differences (DID) approach to analyze the effect of legal status granted under IRCA on the educational access of previously undocumented immigrant youths in the United States. In this setup, the first difference compares changes in college enrollment rates before and after the enactment of IRCA. The second difference is between two immigrant youth groups: a control group who always has permanent legal status (refugees) and a treatment group with undocumented status (economic immigrants). The central assumption of this identification strategy is that no other exogenous factors could explain the differences observed in this time frame.

I follow the methodology outlined in Cortes (2004), which distinguishes refugees from economic immigrants. Using several volumes from the Statistical Yearbook of the Immigration and Naturalization Service (1970-1996), Cortes
(2004) sorts refugees entering the United States by nation of origin, then closely matches those refugees with US census data, using the variables year of immigration and detailed country of birth. ${ }^{3,4}$

The following model specification is estimated by OLS to analyze the effect of IRCA on postsecondary educational access of immigrant youths:

$$
\text { (1) } \begin{aligned}
Y_{i t}= & \alpha+\sum_{k=1975, k \neq 1982}^{1986} \beta_{k} \cdot I\left(\text { Year }_{t}=k\right) \\
& +\gamma \cdot \text { Treat }_{i t}^{\text {econ }}+\delta \cdot \text { IRCA }_{i} \cdot \text { Treat }_{i t}^{\text {econ }} \\
& +X_{i t} \cdot \phi+\varphi+\varepsilon_{i t},
\end{aligned}
$$

where $Y_{i t}$ is a binary variable that indicates college enrollment for immigrant youth $i$ in cohort $t$ (i.e., year of immigration). $I(\cdot)$ is an indicator function associated with immigrant arrival cohort in year $t$. Treat it $_{\text {econ }}$ is a binary variable that is equal to one if the observation is an economic immigrant youth or zero if the observation is a refugee immigrant youth. $I R C A_{i}$ is a binary variable that indicates if immigrant youth $i$ arrived in the United States during the amnesty years. That is, $I R C A_{i}$ is equal to one if immigrant youth $i$ is observed in arrival cohorts 1975-1981 (i.e., amnesty granting period); or equal to zero if immigrant youth $i$ is observed in arrival cohorts 1982-1986 (i.e., no amnesty granting period). $X_{i t}$ is a vector of demographic characteristics that include gender, race/ethnicity, household family size of the immigrant youth, family size squared, and school-level age of arrival indicator variables (preschool: ages 0-4; elementary school: ages 5-10; middle school: ages 11-13; and high school: ages 14-18). $\varphi$ is a vector of fixed effects. Two sets of fixed effects are used to capture unobserved effects of state of residence

\footnotetext{
${ }^{3}$ In her paper, Cortes reports on a detailed set of statistical comparisons of these two groups, in terms of age of arrival, gender, and family composition. Based on her classification developed using the US Census, statistically significant differences in the characteristics between refugee and economic immigrant groups are found.

${ }^{4}$ During the period of 1975-1986, INS classified immigrants from the following countries as refugees: Afghanistan, Cambodia, Cuba, El Salvador, Ethiopia, Haiti, Iran, Laos, Nicaragua, Poland, Romania, the Soviet Union, and Vietnam.
} 


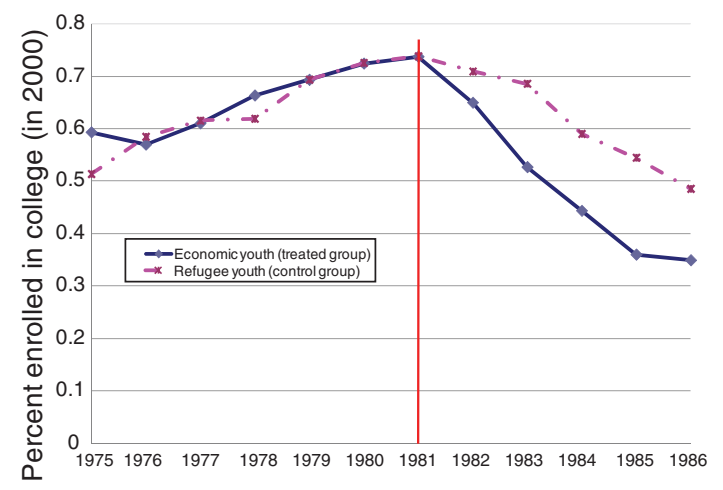

Year of immigration

Figure 1. Percent Enrolled in College in 2000 By IMMIGRANT GROUP AND YEAR OF IMMIGRATION

Notes: Immigrants who arrived in the US from 1975 to 1981 were granted amnesty under IRCA. Immigrants who arrived after 1981 missed the cutoff year for the amnesty eligibility under IRCA.

Source: 2000 Census Public Use Micro Sample (PUMS), author's own tabulations.

and place of birth. $\varepsilon_{i t}$ is a normally distributed random error term.

The coefficients of the above DID framework have the following interpretation: $\beta_{k}$ captures the yearly cohort differences, in the average outcome over time, that are common to both economic and refugee youth groups; $\gamma$ captures the average permanent differences between the groups. Last, and of particular interest, is the coefficient $\delta$, which is the DID estimator that captures the effect of IRCA. This parameter measures the difference in college enrollment before and after IRCA for economic immigrant youths, compared to the corresponding difference for refugee immigrant youths.

The data used in this analysis come from the 5 percent Public Use Sample of the 2000 US decennial census. The analytical sample consists of 33,866 foreign-born immigrant youths who were not older than 18 years of age upon arrival in the United States, and who immigrated to the United States between 1975 and 1986. I examine seven cohorts who were eligible for IRCA (i.e., immigrants who arrived between 1975 and 1981), and five cohorts who were ineligible for IRCA since they missed the cut-off year of immigration (i.e., those who arrived between 1982 and 1986).
Figure 1 presents the 2000 US census differential trends in postsecondary enrollment among economic and refugee immigrant youth. Each line graphs the mean of college enrollment, conditional on year of immigration for both immigrant groups. The figure shows that for economic and refugee youth arriving in the US between 1975 and 1981, the 2000 college enrollment rates of the two groups track each other very closely. In contrast, we see a divergence of these two rates for immigrant youth who arrived after 1981. Figure 1 illustrates the point that economic youths who missed the amnesty period are less likely to enroll in college than economic youths who arrived within the amnesty period.

\section{Empirical Findings and Discussion}

The results for the regression-adjusted DID analysis are reported in Table 1. This table reports only the estimated coefficients on the IRCA indicator variable (i.e., immigrant cohorts who entered the United States before 1982) interacted with the treatment indicator variable (i.e., economic immigrants) and the treatment indicator. All regression standard errors are robust and clustered on state and place of birth interactions. As Table 1 shows, there is a positive and statistically significant DID estimate for all model specifications. Though the magnitude of these point estimates varies slightly, the direction of the estimates is not sensitive to the addition of age at arrival and demographic controls (column 2) and it is fairly robust to the addition of the different sets of fixed effects (columns 3 and 4). The point estimate on the DID estimator ranges between 0.14 and 0.16 . The preferred model specification is shown in column 4 , which includes the full set of covariates and fixed effects and improves the efficiency of the DID estimator. Controlling for demographic characteristics and state-by-place of birth fixed effects, I find that economic immigrant youth who were granted legal status under IRCA are 13.9 percentage points more likely to enroll in college.

In an additional analysis (results not shown), I estimated alternative DID estimators for different policy windows. One concern might be that refugee youths who entered the United States during the years 1975-1981 may be different from those who entered during 1982-1986. To assess the potential compositional change in the control group, I analyzed one, two, and 
Table 1-Difference-In-Differences Regressions, the EfFect of the Immigration Reform AND Control Act (IRCA) on College Enrollment

\begin{tabular}{lcccc}
\hline \hline & $(1)$ & $(2)$ & $(3)$ & $(4)$ \\
\hline IRCA $\times$ treatment & $0.155^{* * *}$ & $0.145^{* * *}$ & $0.144^{* * *}$ & $0.139 * * *$ \\
& $(0.027)$ & $(0.025)$ & $(0.027)$ & $(0.028)$ \\
Treatment (economic immigrant) & $-0.144^{* * *}$ & $-0.114^{* * *}$ & $-0.083^{* * *}$ & $-0.073 * * *$ \\
& $(0.034)$ & $(0.020)$ & $(0.015)$ & $(0.017)$ \\
Constant & $0.775^{* * *}$ & $0.741^{* * *}$ & $0.714^{* * *}$ & $0.710^{* * *}$ \\
& $(0.018)$ & $(0.024)$ & $(0.021)$ & $(0.023)$ \\
Immigrant cohort (year dummies) & Yes & Yes & Yes & Yes \\
School level: age at arrival & & Yes & Yes & Yes \\
Demographics & & Yes & Yes & Yes \\
Place of birth fixed effects & & & & Yes \\
State-by-place of birth fixed effects & & & 33,866 & 33,866 \\
Observations & 33,866 & 33,866 & 0.15 & 0.20 \\
$R^{2}$ & 0.08 & 0.14 & & \\
\hline
\end{tabular}

Notes: Sample consists of foreign-born individuals who arrived to the United States from 1975 through 1986 and by age 18. Robust standard errors (shown in parentheses) clustered at the state $\times$ place of birth. See text for list of control variables. Mean college enrollment rate is 0.55 . *** Significant at the 1 percent level.

Table 2-Alternative Difference-In-Differences Regressions, the EfFect of IRCA on College Enrollment by Specific Country of Origin

\begin{tabular}{|c|c|c|c|c|}
\hline & \multicolumn{2}{|c|}{ Latin America } & \multicolumn{2}{|c|}{ Southeast Asia } \\
\hline & (1) & (2) & (1) & (2) \\
\hline IRCA $\times$ treatment & $\begin{array}{l}0.147 * * * \\
(0.017)\end{array}$ & $\begin{array}{l}0.104 * * * \\
(0.015)\end{array}$ & $\begin{array}{l}0.087 * * \\
(0.042)\end{array}$ & $\begin{array}{l}0.091 * * \\
(0.037)\end{array}$ \\
\hline Treatment (economic immigrant) & $\begin{array}{l}-0.212 * * * \\
(0.024)\end{array}$ & $\begin{array}{l}-0.162 * * * \\
(0.014)\end{array}$ & $\begin{array}{c}0.024 \\
(0.044)\end{array}$ & $\begin{array}{c}0.019 \\
(0.029)\end{array}$ \\
\hline Constant & $\begin{array}{l}0.715^{* * * *} \\
(0.024)\end{array}$ & $\begin{array}{l}0.662 * * * \\
(0.029)\end{array}$ & $\begin{array}{l}0.733 * * * \\
(0.019)\end{array}$ & $\begin{array}{l}0.647 * * * \\
(0.043)\end{array}$ \\
\hline $\begin{array}{l}\text { Immigrant cohort (year dummies) } \\
\text { School level: age at arrival } \\
\text { Demographics } \\
\text { State fixed effects }\end{array}$ & Yes & $\begin{array}{l}\text { Yes } \\
\text { Yes } \\
\text { Yes } \\
\text { Yes }\end{array}$ & Yes & $\begin{array}{l}\text { Yes } \\
\text { Yes } \\
\text { Yes } \\
\text { Yes }\end{array}$ \\
\hline Observations & 10,209 & 10,209 & 5,268 & 5,268 \\
\hline$R^{2}$ & 0.14 & 0.19 & 0.05 & 0.08 \\
\hline
\end{tabular}

Notes: Sample consists of foreign-born individuals who arrived to the United States from 1975 through 1986 and by age 18. Robust standard errors (shown in parentheses) clustered at the state $\times$ place of birth. See text for list of control variables. Mean college enrollment rate for Latin America and Southeast Asia subgroups are 0.44 and 0.67 , respectively.

*** Significant at the 1 percent level.

** Significant at the 5 percent level.

three years on either side of the policy window. Looking at smaller time periods is a way to gauge the sensitivity of the previous DID estimators. These alternative DID estimators are very comparable to the previous ones reported in Table 1. I find that at one year on either side of the policy window, college enrollment increased by 15.8 percentage points for economic immigrant youth who were given legal status under IRCA.

It is well documented that the majority of immigrants who were granted legal status under 
IRCA predominantly came from Latin America: 71 percent were from Mexico, 11 percent from Central America, and all other countries contributed the remaining 18 percent (Chiswick 1988). Table 2 reports DID results by two specific regions of origin: Latin America and Southeast Asia. The unadjusted DID estimates for the Latin America analysis are larger in magnitude than those for the Southeast Asia analysis: 14.7 versus 8.7 percentage points, respectively. Conditioning on demographic characteristics and state fixed effects, I find that economic youth from Latin America and Southeast Asia who were granted legal status under IRCA are 10.4 and 9.1 percentage points, respectively, more likely to enroll in postsecondary education.

\section{Concluding Remarks}

The results here show that immigrant youth are more likely to enroll in college when legal barriers are removed and financial barriers lowered. The point estimates are not strictly comparable to those found in Kaushal (2008), Flores (2010), and Chin and Juhn (2010) since we are looking at two distinct time periods and policies. The previous studies analyzed laws passed in early and mid 2000s, which provided access to in-state tuition to undocumented students. This study, by contrast, considers immigrant youth who were given amnesty between 1975 and 1981. Still, the estimated magnitudes of college enrollment among immigrant youth identified here are quite similar to those identified by Kaushal (2008). Using the preferred DID estimate of 13.9 percentage points, for example, I find a 25 percent increase over the base college enrollment of 55 percent.

\section{REFERENCES}

Amuedo-Dorantes, Catalina, and Cynthia Bansak. 2011. "The Impact of Amnesty on Labor Market Outcomes: A Panel Study Using the Legalized Population Survey." Industrial Relations 50 (3): 443-71.

Amuedo-Dorantes, Catalina, Cynthia Bansak, and Steven Raphael. 2007. "Gender Differences in the Labor Market: Impact of IRCA's Amnesty Provisions." American Economic Review 97 (2): 412-16.
Chin, Aimee, and Chinhui Juhn. 2010. "Does Reducing College Costs Improve Educational Outcomes for Undocumented Immigrants? Evidence from State Laws Permitting Undocumented Immigrants to Pay In-state Tuition at State Colleges and Universities." In Latinos and the Economy: Integration and Impact in Schools, Labor Markets, and Beyond, edited by David L. Leal and Stephen J. Trejo, 63-94. New York: Springer.

-Chiswick, Barry R. 1988. "Illegal Immigration and Immigration Control." Journal of Economic Perspectives 2 (3): 101-15.

-Cortes, Kalena E. 2004. "Are Refugees Different from Economic Immigrants? Some Empirical Evidence on the Heterogeneity of Immigrant Groups in the United States." Review of Economics and Statistics 86 (2): 465-80.

-Flores, Stella M. 2010. "State Dream Acts: The Effect of In-State Resident Tuition Policies and Undocumented Latino Students." The Review of Higher Education 33 (2): 239-83.

-Kaushal, Neeraj. 2008. "In-State Tuition for the Undocumented: Education Effects on Mexican Young Adults." Journal of Policy Analysis and Management 27 (4): 771-92.

-Kossoudji, Sherrie A., and Deborah A. CobbClark. 2002. "Coming Out of the Shadows: Learning about Legal Status and Wages from the Legalized Population." Journal of Labor Economics 20 (3): 598-628.

-Pan, Ying. 2012. "The Impact of Legal Status on Immigrants' Earnings and Human Capital: Evidence from the IRCA 1986." Journal of Labor Research 33 (2): 119-42.

Passel, Jeffrey S., and Mark H. Lopez. 2012. "Up to 1.7 Million Unauthorized Immigrant Youth May Benefit from New Deportation Rules." Washington, DC: Pew Hispanic Center.

- Rivera-Batiz, Francisco L. 1999. "Undocumented Workers in the Labor Market: An Analysis of the Earnings of Legal and Illegal Mexican Immigrants in the United States." Journal of Population Economics 12 (1): 91-116.

US Immigration and Naturalization Service. 1970-1996. Statistical Yearbook of the Immigration and Naturalization Service. Washington, DC: U.S. Government Printing Office.

US Supreme Court Reports. Plyler, Superintendent, Tyler Independent School District, et al. v. Doe, Guardian, et al. 457 U.S. 202. No. 80-1538 (1982). 